\title{
Evaluation of the diversity of Scolitids (Coleoptera: Curculionidae) in the forest plantations of the central zone of the Ecuadorian littoral
}

\section{Diversidad de escolítinos (Coleoptera: Curculionidae) en plantaciones forestales de la zona centro del Litoral ecuatoriano}

\author{
${ }^{\bullet}$ Malena Martínez ${ }^{1}$, Jessenia Castro ${ }^{1}$, Ronald Villamar-Torres ${ }^{2,3}$, Mercedes Carranza ${ }^{1}$, Julio Muñoz-Rengifo ${ }^{2,4}$, Edwin Jiménez ${ }^{1}$, \\ Marcelino Guachambala ${ }^{5}$, Marcos Heredia-Pinos ${ }^{2}$, Luz García-Cruzatty ${ }^{6}$ and Seyed Mehdi-Jazayeri ${ }^{7}$ \\ ${ }^{1}$ Universidad Técnica Estatal de Quevedo. Facultad de Ciencias Ambientales. Carrera Ingeniería Forestal. Campus Ing. \\ Manuel Haz Álvarez, km 1.5 vía a Santo Domingo de los Tsáchilas. EC.120501. Quevedo, Ecuador. \\ `mmartinez@uteq.edu.ec; jcastroo@uteq.edu.ec; mcarranza@uteq.edu.ec; ejimenez@uteq.edu.ec \\ ${ }^{2}$ Secretaría de Educación Superior, Ciencia, Tecnología e Innovación. Whymper E7-37 y Alpallana \\ Código Postal: 170516. Quito, Ecuador. \\ ${ }^{3}$ Université de Montpellier. Programme de Doctorat en Biologie Intégrative. Diversité et Amélioration des Plantes. France. \\ 163 rue Auguste Broussonnet - 34090 Montpellier. ronald.villamar-torres@ird.fr; villamartorresronaldoswaldo@yahoo.es \\ ${ }^{4}$ Universidad Estatal Amazónica. Carrera de Ingeniería Agropecuaria. Departamento Ciencias de la Tierra. Alvaro Valladres y \\ Cristóbal Colón. Puyo, Pastaza, Ecuador.jcmr_pocholo@hotmail.com \\ ${ }^{5}$ Plantaciones de Balsa Plantabal S.A. 3AComposites. Km 5 vía Valencia. Valencia, Ecuador. marcelino36_1@hotmail.com \\ ${ }^{6}$ Universidad de Técnica de Manabí. Facultad de Ingeniería Agronómica. Campus Experimental "La Teodomira", km 13 1/2 vía \\ Santa Ana. Santa Ana, Manabi, Ecuador. cecilialuz29@hotmail.com \\ ${ }^{7}$ Universidad Nacional de Colombia. Facultad de Ciencias. Departamento de Biología. Carrera 30 \# 45-03. Edif. 476. \\ Bogotá, Cundinamarca, Colombia.
}

Rec.: 14.04.2017. Acept.: 21.08.2017. Publicado el 1 de diciembre de 2017

\section{Abstract}

$\mathrm{T}$ he species of Scolytinae subfamily have a worldwide distribution, and are found mainly in the Neo-tropic regions. They usually dominate the communities of wood borer insects. The aim of the present study was to determine the diversity among Scolytinae species associated with balsa, teak, rubber and gamhar plantations located in the humid tropical zone of the Ecuadorian littoral. In each plantation seven flight interception traps containing an ethanol / gel mixture were installed, with a collection frequency of 15 days for three months in the dry period. A total of 1437 specimens were collected, represented by Xyleborini, Cryphalini, Corthylini and Ipini tribes. In the four plantations, 18 species of Scolitids were collected, of which 16 were recorded in the balsa plantation, while in the other plantations 10 to 12 species were found. The most abundant Scolitids were Hypothenemus spp., Corthylus spp., Xyleborus affinis, Xyleborinus bicornatulus and Premnobium cavipennis. The Shannon-Wiener diversity index was higher in the balsa culture $\left(H^{\prime}=2.37\right)$ and lower in Teak $\left(H^{\prime}=1.57\right)$. The Jaccard similarity index was higher among the teak and rubber plantations $(\mathrm{Cj}=0.9090)$ while the balsa plantation obtained less similarity with respect to the other three plantations. The greatest diversity of Scolitids was recorded in the balsa plantation, which is a native species, unlike the other forest species, which are exotic, indicating that the diversity would be influenced by the host tree and the location where they are found.

Key words: Scolitids, diversity, balsa, teak, Ecuador, gamhar, rubber.

\section{Resumen}

I as especies de la subfamilia Scolytinae tienen una distribución global, abundan principalmente en el Neo trópico y dominan usualmente las comunidades de insectos barrenadores de la madera. El objetivo del presente estudio fue determinar la diversidad de las especies Scolytinae asociadas a plantaciones de balsa, teca, caucho y melina, en la zona tropical húmeda del litoral ecuatoriano. En cada plantación se instalaron siete trampas de interceptación de vuelo conteniendo una mezcla de etanol/gel, con una frecuencia de recolección de 15 días durante tres meses en el periodo seco. En total se recolectaron 1437 especímenes, representados por las tribus Xyleborini, Cryphalini, Corthylini e Ipini. En las cuatro plantaciones se colectaron 18 especies de escolítinos, de las cuales, 16 se registraron en la plantación de balsa, mientras que en las otras plantaciones se encontraron entre 10 y 12 especies. Los escolítinos con mayor abundancia fueron Hypothenemus spp., Corthylus spp., Xyleborus affinis, Xyleborinus bicornatulus y Premnobium cavipennis. El índice de diversidad de Shannon-Wiener fue mayor en el cultivo de balsa $\left(\mathrm{H}^{\prime}=2.37\right)$ y menor en teca $\left(\mathrm{H}^{\prime}=1.57\right)$. El índice de similitud de Jaccard fue mayor entre las plantaciones de teca y caucho $(\mathrm{Cj}=0,9090)$ mientras que la balsa obtuvo menor similitud con respecto a las tres plantaciones. La mayor diversidad de escolítinos se registró en la plantación de balsa, que es una especie nativa, a diferencia de las otras especies forestales, que son éxoticas, indicando que la diversidad, estaría influenciada por el árbol hospedero y la localidad donde estas se encuentran.

Palabras clave: escolítidos, diversidad, balsa, teca, Ecuador, melina, caucho. 


\section{Introduction}

$\mathrm{F}$ orest masses play an important role in erosion control, filtration (FAO, 2009), climate regulation (Balvanera, 2012), etc. In general, they can provide infinity of imperceptible ecosystem services (MEA, 2003) such as regulation (Maass et al., 2005) of the impact of emissions (IPCC, 2013). Strong pressures with possible recurrences on the ecosystems (IUFRO, 2017), which alter the forest masses, affect the health of the vegetation that could cause disease occurrence, pest attacks toward mortality (Garcia de la Serrana et al., 2015), with greater impact on forest masses in Latin America and the Caribbean, due to their vulnerability (Cepal, 2010). In that sense, some approaches have been described to improve the conditions of plants in nursery (Muñoz et al., 2014), the nutritive condition enhancements for plantation (Caballero, 2017), the orientation of the slope considering the plantation in irregular areas (Carter and Klinka, 1990), and the forest management protocols (Coronado, 2017), generally at a productive level, in order to ameliorate plantation conditions to take advantage of market prices (Lopez et al., 2014).

According to Nicholls (2017) some authors have analyzed the impact of global warming on crop production. The increase in temperatures above an optimum level for vegetation causes decay (Arregui, 2016) and more vulnerability to be attacked by pests (Kjohl et al., 2012) those in some cases are associated with the climate (Iturre and Darchuck, 1996). In this case, one of the main concerns related to any disturbance that affects the health of plants is attack of drillers (Romanyk, 1961) like Scolitids. Insects found in the forest ecosystems constituted of 247 genera and 5990 species (Hulcr et al., 2015; Kirkendall et al., 2015).

The beetles perforate the bark of trees and build galleries (Coitía and Rosales, 2001). They are divided into two groups depending on the food habit: the bark beetles (xylophages), which feed phloem tissue, and those of ambrosia correlated to symbiont fungi (xylomicetophages) (Hulcr et al., 2015; Wood, 2007), which are mostly found in tropical zones (Wood, 2007).

Of the presented species diversity, $79 \%$ is found in tropical and subtropical ecosystems (Kirkendall et al., 2015), 38\% are described in South America corresponding to collections from Mexico, Central America, Colombia, Venezuela and Brazil, and represent only one third of the Scolitids of this region (Wood, 2007). Among those recorded for bark and ambrosia beetles of the region, 50 species are determined as Ecuador contribution, which does not represent all the diversity of Scolitids in the region. Current studies have described new species such as Akrobothrus ecuadoriensis (Dole and Cognato, 2007), Coptoborus ochromactonus Smith and Cognato for their economic importance (Stilwell et al., 2014) and Coptonotus uteq Smith and Cognato in tropical rainforest "Murocumba "(Cognato and Smith, 2016).

The Scolitids participate in nutrient recycling, as they firstly prefer to attack sick or injured plants (Wood, 2007). However, $1 \%$ of species attack healthy standing trees (Kirkendall et al., 2015). Although the massive attack of Scolitids is rare in healthy tropical forests (Wood, 2007), currently in South America and Europe some reports of damage to forest plantations by native Scolitids such as Corthylus zulmae attacking alder (Alnus acuminata) H.B.K. in Colombia (Jaramillo et al., 2011); Premnobium cavipennis Eichhoff affecting Eucalyptus clones in Brazil (Zanuncio et al., 2005), Tomicus destruens and Tomicus piniperda attacking Pinus halepensi in Europe (Durand-Guilman, 2014) and Coptoborus ochromactonus Smith and Cognato associated with regressive death of balsa tree (Ochroma pyramidale (Cam ex. Lam) in Ecuador (Stilwell et al., 2014) have been published.

The stability of plantations, as well as wood quality and regressive death of the balsa tree (Ochroma pyramidale) associated with $C$. ochromactonus is a precedent that could affect forest plantations in Ecuador. In addition to balsa tree, teak (Tectona grandis L.), rubber (Hevea brasilienses (Willd. Ex A. Juss.) Moll. Arg. and gamhar (Gmelina arborea Roxb.), are crops of economic importance considered in the national program of forest incentives, which in recent years have reached to 6933.7 hectares of plantation (MAGAP, 2015).

Due to the importance of the Scolitids in the forest plantations and diversity scarce information of species present in the central area of the Ecuadorian coast, this work has initially been aimed to identify the diversity of the Scolitids associated with plantations of balsa, teak, rubber and gamhar, in the months of the annual dry period in the central area of the Ecuadorian coast, to later deepen in a second investigation to molecular characterization level of the scolitids, which will be descripted in next papers.

\section{Materials and methods}

$T_{p}^{\mathrm{h}}$ he research was carried out in four sites: 1) A balsa plantation located in the Guasaganda parish, La Maná canton, Cotopaxi province at 590 masl $704909.18 \mathrm{~m} \mathrm{E}$, $9911842.22 \mathrm{~m} \mathrm{~S}$; 2) a teak plantation located in La Cumbia, Valencia canton, Los Ríos province at 60 masl, $672584 \mathrm{~m} \mathrm{E}$, 990,833 m S; 3) a rubber plantation, Los Ángeles campus, Buena Fe canton, Los Ríos province at 155 masl $675062.54 \mathrm{~m}$ E, $9932004.16 \mathrm{~m} \mathrm{~S}$, and 4) a gamhar plantation located in the Bimbe del Toachi area, Valencia canton, Los Ríos province at 276 masl $692038.62 \mathrm{~m} \mathrm{E}, 9953921.93 \mathrm{~m} \mathrm{~S}$.

In each plantation seven circular plots of $500 \mathrm{~m}^{2}$ were delimited with a radius of $12.62 \mathrm{~m}$, distanced at $200 \mathrm{~m}$ in a straight line. At the center of each plot, a suspended interception trap was placed at height of $1.3 \mathrm{~m}$, using ropes tied to the trees. The Bambara trap model ((Hulcr et al., 2008) was used, which consisted of placing a $1000 \mathrm{~mL}$ plastic bottle, 
with an opening side for the entrance of insects and a plastic plate on top to avoid the entry of plant residues and water. They were placed in a mixture of alcohol $70^{\circ} /$ disinfectant gel (Carbopol-Trieta-Ethanol $70 \%$ and water $30 \%$ ) in a ratio of 3:1.

Sampling was carried out in the months of the dry period, from June to August 2014. The collection and replacement of attractants was carried out every 15 days. The material collected in the traps was cleared by removing the lid of the bottle and placing the material in other flasks, which were labeled and taken to the microbiology laboratory of the Universidad Técnica Estatal of Quevedo-Ecuador. Each sample was placed in Petri dishes and an initial classification was carried out according to the morphological characters in order to count the insects. The identification was made at the tribe level and in some cases at the level of genus or species, by using dichotomous identification keys (Wood, 2007), which are comparisons with a collection of Scolitids validated by the entomology department of the Michigan State University.

To compare the diversity of Scolitids in the different forest plantations, the Shannon-Wiener diversity index (H') and the Simpson dominance index (D) that measure the structure of community; Jaccard similarity index, cluster analysis, dominance and species richness were calculated using the statistical program PAST version 2.15 (Hammer et al., 2001).

\section{Results and Discussion}

\section{Scolitids fauna}

We collected 1437 individuals represented by the Xyleborini, Corhtylini, Cryphalini and Ipini tribes. These tribes are also reported by Ferreira (2016), Pérez (2008), both in plantations and agroforestry systems, being the most representative tribes in South America, in agreement with what was indicated by Wood (2007). In the balsa plantation, $81 \%$ of the Scolitids corresponded to the Corthylini and Xyleborini tribes. In the teak plantation, there was a greater abundance of Scolitids of the Cryphalini tribe, which reached to $43 \%$, coinciding with what was stated by Ferreira (2016). This finding indicates that Scolitids of the Criphalini tribe predominated in the teak plantations. In the rubber plantation, the Xyleborini and Cryphalini tribes were in the majority, while in the gamhar plantation there were a greater number of individuals of the Xyleborini tribe (Figure 1).

The Xyleborini tribe with 499 individuals and Corthylini with 418 individuals presented five genera, these quantities differ from the values reported by Pérez (2008), however, it highlights the greater number of genera captured from these tribes. While Cryphalini with 409 individuals and Ipini with 111 individuals had two and one genus respectively. 18 species were collected in the four forest plantations, with a greater number of individuals of Hypotenemus sp, Corthylus sp. (3) and Xyleborus affinis, Xyleborinus bicornatulus and Premnobium cavipennis (Table 1). These Scolitids are likely to adapt and take better advantage of resources, especially $X$. affinis, which was the most abundant as indicated previously (Rangel et al., 2012), due to the wide natural distribution and host species (Pérez, 2008). The highest abundance of Scolitids was recorded in the rubber plantation with 440 individuals. However, the number of species (10) was lower than those collected in the balsa plantation (16), which represents $88 \%$ of the species diversity. The gamhar plantation had lower abundance and was correlated with the lower number of species (Table 1). The diversity of species present in the balsa plantation could be linked to the fact that this species is native to Ecuador and several countries of South America (Stephen et al., 2010), while the other species have been introduced into the country. On the other hand, the characteristics of balsa tree among them the hardness $\left(0.22 \mathrm{~g} / \mathrm{cm}^{3}\right)$, the chemical

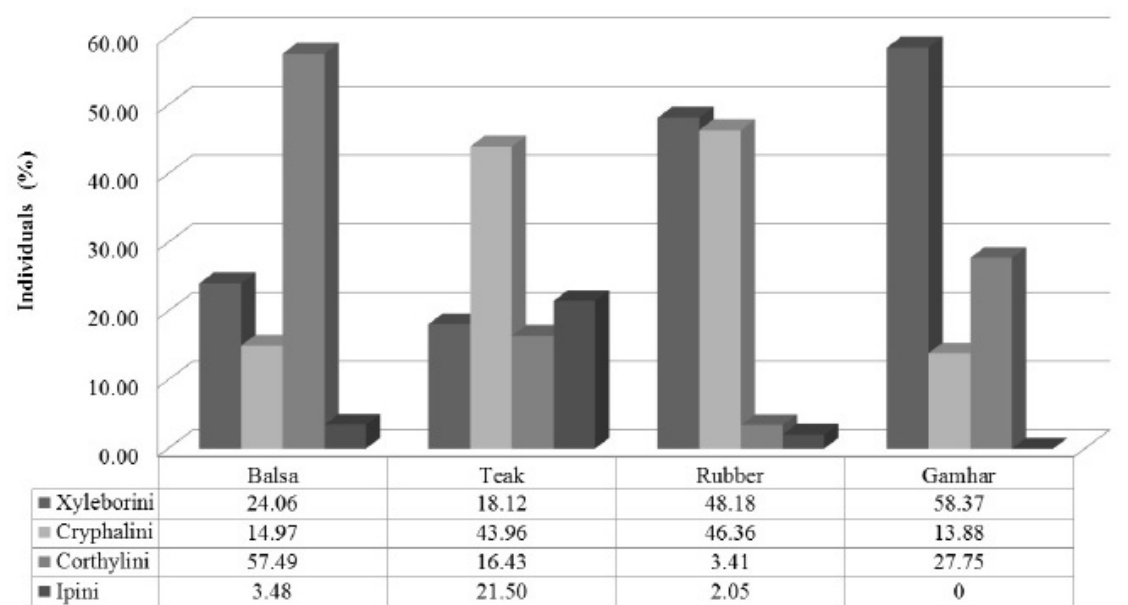

Figure 1. Abundance of Scolitids at the tribe level in the forest plantations of the central area of the Ecuadorian littoral 
composition as the presence of sterols: $\beta$-sitosterol and stigmasterol; coumarin scopoletin and cleomiskin in wood (Fonseca da Paula et al., 1995) can be responsible for the disclosed diversity seen in the balsa plantation. In addition, the phytosanitary problems, which are greater in the culture of balsa, and preference of many Scolitids to choose dead or weakened trees for reproduction (Rudinsky, 1962) are other factors in the diversity found for the balsa plantation.

The most abundant Scolitids among balsa trees were Corthylus sp. (2) (23.3\%) and Corthylus sp. (3) (17.6\%), reaching to more than $40 \%$ among all. This genus was also recorded in the other crops in smaller quantity. This wide distribution and abundance is due to the fact that this genus is numerous and possesses Neotropical distribution as indicated by Wood (2007). In addition, Hypotenemus sp. (15\%) and C. ochromactonus $(6.7 \%)$ are highlighted. The latter was collected only in the balsa plantation, as done for Theoborus sp., Microcorthylus vietus, Corthylus insigni, Corthylus pigmaeus and Corthylus sp. (4) (Table 1). Species such as C. insigni present in both balsa and rubber plantation, and $C$. pygmaeus only in the balsa trees, are reported for Colombia and Costa Rica, correlated with Inga and Theobroma respectively (Wood, 2007). We report that the species C. pygmaeus is recorded for the first time in the balsa plantation for Ecuador. In this study, C. ochromactonus was captured only in the balsa plantation, considered as a pest of economic importance. Although the plantation under study is in a location whose characteristics correspond to pre-mountain humid forest, this species is reported to be related to the balsa plantation in other locations whose characteristics correspond to tropical and tropical dry forest in the dry and rainy period respectively (Stilwell et al., 2014). In the case of Theoborus sp. and $C$. pygmaeus captured only in the balsa plantation, there are no previous studies indicating that it is correlated with the other crops and important to carry out studies on these forest crops.

In the teak plantation, 414 individuals represented in 10 species were collected, of these, Hypotenemus sp. (44\%), P. cavipennis (21.5\%), Corthylus sp. (3) (16.4\%) and $X$. affinis $(8.2 \%)$ were presented in greater quantity. In a smaller proportion, Xyleborus spinulosus (3.6\%), Xyleborinus bicornatulus (3.1\%), Xylosandrus sp. (2.6\%) and Xyleborus ferrugenius $(0.5 \%)$ (Table 1$)$ were also found. In the teak plantation, the species with the highest number was Hypothenemus sp. Although no damage was observed in the trees to determine its attack as a primary or secondary pest, its quantity in this plantation is relevant. Studies on the physiological conditions of the tree and the abundance of the insect should be related to the degree of destruction (Rudinsky, 1962). In Ghana, Hypothenemus pusillus is considered as stem borer in teak plantations (Nair, K. S. 2000). Premnobius cavipennis, presented also a considerable number of individuals. This association is reported in teak forests in Brazil, in the state of Do Paraná, although its multitude was low (Ferreira, 2016).
In the rubber plantation, 440 Scolitids were collected, with a number of the species Hypotenemus sp. (25.5\%), X. bicornatulus (25.5\%), X. affinis (17.3\%) and Corthylus sp. (3) (14.1\%). Cryptocarenus hevea with $5.2 \%$ was present only in this plantation (Table 1). The population of Scolitids was biased towards the species of the Xyleborini tribe, differing from that found in Brazil, where the population of Scolitids was concentrated in the Cryphalini tribe (Pereira et al., 2015). However, the species Hypotenemus sp. and C. hevea, collected in Ecuador are also reported in the rubber plantations in Brazil (Pereira et al., 2015). Although the population of $C$. hevea was not high, this species was only recorded in this crop. Among the species Xyleborinus bicornatulus and Xyleborus affinis linked to this plantation is also reported in the rubber plantations in Brazil (Pereira et al., 2015). Likewise, Xyleborus affinis is reported attacking rubber lumber in Thailand (Sittichaya and Beaver, 2009, Kangkamanee et al., 2011). X. affinis and $X$. ferrugineus are considered as economic important species because they can cause large infestations in tropical wood with similar characteristics, however, in the studied plantations the population of $X$. ferrugineus was low. As rubber is comparatively free of pests and insects in natural or established forests, this is attributed to the production of latex in all parts of the plant.

In the gamhar plantation, 209 Scolitids were collected. The species with the greatest number were: $X$. affinis $(40.7 \%)$, Xylosandrus morigerus (14.8\%), Corthylus sp. (3) (14.4\%), and Hypotenemus sp. (13.9\%). In lower abundance, $X$. ferrugenius (1.4\%), X. bicornatulus (1.4\%) and Tricolus sp. $(1.4 \%)$ (Table 1) were found. Although the attack is secondary, these species can cause damages of economic importance due to their abundance and wide variety of hosts (Beaver et al., 2014). X. affinis is reported in gamhar (Vásquez, 2003). The genus Xyleborus is present in all the studied plantations, this group of species has been considered of great importance in tropical ecosystems (Morales et al., 2000). Xylosandrus spp. has been found abundantly in gamhar. This genus representing an economic important species can attack and reproduce in healthy branches and shoots of forest trees; as they can also transmit pathogenic fungi (Beaver et al., 2014).

\section{Analysis of the diversity of Scolitids associated with forest plantations}

The number of Scolitids varied in each plantation. The rubber cultivation had the highest abundance of Scolitids, but where the greatest species richness occurred was in the balsa plantation with 16 species. This is reflected in the diversity index of obtained species. In the balsa cultivation where a normal diversity was found according to the Shannon index, it ranges between 2 and $3\left(H^{\prime}=2.37\right)$ while the teak plantation showed low diversity $\left(\mathrm{H}^{\prime}=1.57\right)$. In the plantation of rubber and gamhar, the diversity of Scolitids was quite similar (Table 2). The variation of the diversity obtained in the different forest crops would be related to what was stated by Gohli et 
Table 1. Fauna and abundance of Scolitids in forest plantations in the central area of the Ecuadorian littoral

\begin{tabular}{lrrrrrr}
\hline Species & Balsa & Teak & Rubber & Gamhar & Total & Percentage \\
\hline Xyleborini & & & & & & \\
Coptoborus ochromactonus & 25 & 0 & 0 & 0 & 25 & 1.70 \\
Xyleborus affinis & 13 & 34 & 76 & 85 & 208 & 14.50 \\
Xyleborus spinulosus & 12 & 15 & 4 & 0 & 31 & 2.20 \\
Xyleborus ferrugineus & 0 & 2 & 2 & 3 & 7 & 0.50 \\
Xyleborinus bicornatulus & 22 & 13 & 112 & 3 & 150 & 10.40 \\
Xylosandrus morigerus & 10 & 11 & 18 & 31 & 70 & 4.90 \\
Theoborus sp. & 8 & 0 & 0 & 0 & 8 & 0.60 \\
Ipini & & & & & & \\
Premnobius cavipennis & 13 & 89 & 9 & 0 & 111 & 7.70 \\
Corthylini & & & & & & \\
Microcorthylus vietus & 20 & 0 & 0 & 0 & 20 & 1.40 \\
Tricolus & 5 & 0 & 2 & 3 & 10 & 0.70 \\
Corthylus insigni & 6 & 0 & 0 & 2 & 8 & 0.60 \\
Corthylus pygmaeus & 14 & 0 & 0 & 0 & 14 & 1.00 \\
Corthylus sp. (1) & 12 & 1 & 9 & 10 & 32 & 2.20 \\
Corthylus sp. (2) & 87 & 1 & 4 & 13 & 105 & 7.30 \\
Corthylus sp. (3) & 66 & 66 & 62 & 30 & 224 & 15.60 \\
Corthylus sp. (4) & 5 & 0 & 0 & 0 & 5 & 0.30 \\
Cryphalini & & & & & & \\
Hypotenemus sp. & 56 & 182 & 119 & 29 & 386 & 26.90 \\
Cryptocarenus hevea & 0 & 0 & 23 & 0 & 23 & 1.60 \\
Total individuals & 374 & 414 & 440 & 209 & 1437 & 100.00 \\
\hline Total species & 16 & 10 & 12 & 10 & 18 & \\
\hline & & & & & &
\end{tabular}

al. (2017) who indicate that genera that exhibit interspecific variation in the type of host, have higher rates of species diversification.

This suggests that the change of host is a factor of species diversification or that certain types of hosts or forest compositions facilitate colonization and, therefore, allopatric speciation. In addition, the plantations under study were located in different parts, where the climatic conditions differ, although this information was not recorded, these results allow us to infer that the conditions of a site influence species diversification. Using the Simpson index, the values were close to 1 , implying that in the different plantations the communities were represented by more than one species. Regarding the equity index $(\mathrm{J})$, the maximum value was obtained in the balsa

Table 2. Analysis of the diversity of Scolitids captured in the forest plantations of the central area of the Ecuadorian littoral

\begin{tabular}{lccccc}
\hline Plantaciones forestales & Abundancia & Riqueza & $\begin{array}{c}\text { Diversidad } \\
\text { (H') }\end{array}$ & $\begin{array}{c}\text { Diversidad } \\
\text { (D) }\end{array}$ & $\begin{array}{c}\text { Equidad } \\
\text { (J) }\end{array}$ \\
\hline Balsa & 374 & 16 & 2.372 & 0.874 & 0.855 \\
Teak & 414 & 10 & 1.570 & 0.725 & 0.682 \\
Rubber & 440 & 11 & 1.717 & 0.779 & 0.716 \\
Gamhar & 209 & 10 & 1.747 & 0.766 & 0.759 \\
\hline
\end{tabular}




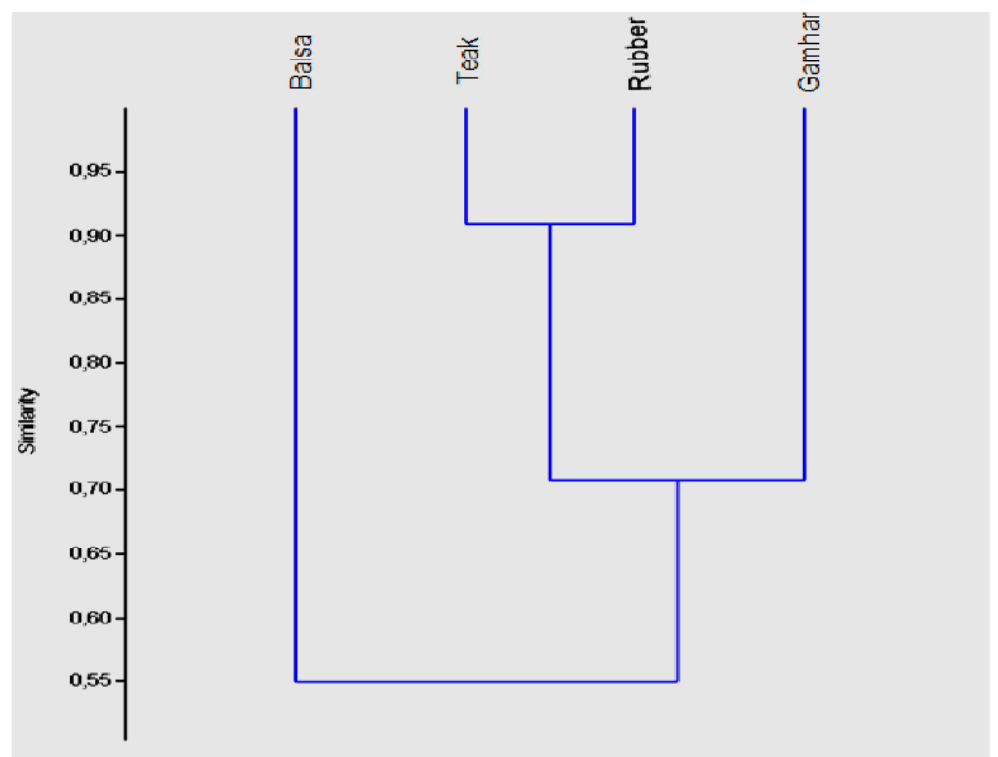

Figure 2. Scolitids similarity dendrogram captured in the forest plantations of the central area of the Ecuadorian littoral

plantation $(\mathrm{J}=0.8554)$, indicating that there was a greater probability that all the species present in the crop were equally abundant, unlike the other crops, which present lower values, especially in the teak plantation (Table 2). The Similarity of species among the plantations showed different values. In the teak and rubber cultivation the similarity of species was high (0.909), while the most distant was for the balsa plantation in relation to the other trees (Figure 2).

\section{Conclusion}

$\mathrm{T}$ he Scolitids present in the four studied plantations are distributed in the tribes Xyleborini, Corthylini, Cryphalini and Ipini. The greater diversity of Scolitids recorded in the balsa plantation and the difference in similarity with the Scolitids present in the other plantations could be related to the fact that balsa tree is a native species in Ecuador, and both the host tree and the Scolitids have adapted to each other based on their environment. The presence of Scolitids like Coptobrus ochromactonus and Cryptocarenus hevea in the balsa and rubber plantation respectively, allow us to deduce that the diversity of Scolitids could be determined by the forest species.

\section{Bibliography}

Arregui, RZ., \& Pérez, LS. (2016). Resistencia de los pinos a plagas y enfermedades: nuevas oportunidades de control fitosanitario. Cuadernos de la Sociedad Española de Ciencias Forestales, (39). Recuperado a partir de http:// secforestales.org/publicaciones/index.php/cuadernos secf/article/view/17466

Balvanera, P. (2012). Ecosystem services supplied by tropical forests. Ecosistemas 21(1-2):136-147.

Beaver, R., Sittichaya, W., Liu, L-Y. (2014). A Synopsis of the Scolytine ambrosia beetles of Thailand (Coleoptera: Curculionidae: Scolytinae). Zootaxa 3875 (1): 001-082.

Caballero, PM. (2017). Evaluación agronómica de plantas de Teak (Tectona grandis L.) a la aplicación de NPK, en el sector Gramalote, cantón Ventanas, provincia Los Ríos (Bachelor's thesis, Universidad Estatal de Bolívar. Facultad de Ciencias Agropecuarias, Recursos Naturales y del Ambiente. Escuela Ingeniería Forestal).

Cognato, AI. (2013). Molecular phylogeny and taxonomic review of Premnobiini brownw, 1962 (Coleoptera: Curculionidae: Scolytinae). Frontiers in Ecology and Evolution 1:1-12.

Coronado, G., \& Alexander, H. (2017). Elaboración De Un Protocolo Para Las Compensaciones Relacionadas Con Los Procesos Forestales En Cerro Matoso SA.

Coitía, W., \& Rosales, CJ. (2001). Relación entre la incidencia de escolítidos y la necrosis del cacao en Aragua, Venezuela. Manejo Integrado de Plagas, 62, 65-71.

Dole, SA., \& Cognato, AI. (2007). A New Genus and Species of Bothrosternina (coleoptera: Curculionidae: Scolytinae) from Ecuador. The Coleopterists Society 61(2), 318-325.

Durand-Gillmann, M. (2014). Interactions plantes-insectes dans deux écosystèmes forestiers méditerranéens contrastés: le cas des scolytes (Coleoptera: Curculionidae: 
Scolytinae) en région méditerranéenne. Thèses doctorat. Aix-Marseille Université, France. 176p.

FAO. (2009). Los bosques y el agua. Estudio FAO Montes 155. Food and Agriculture Organization of the United Nations (FAO), Roma, Italia.

Ferreira, DS. (2016). Diversidade de curculionidae (Scolytinae, Platypodinae) e Bostrichidae en plantios de teca, Tectona grandis L. f., 1782. No estado do Pará, Brasil. Tesis de Maestría en Agroecología e Desenvolvimiento Rural, Universidade Federal deSão Carlos, Brasil. 77p.

Fonseca Da Paula, Vanderlucia, Barbosa, LCA., Howarth, OW., Cash, QB., Vieira, IJ. (1995). Lignans from Ochroma lagopus Swartz. Tetrahedron. 51 (45): 1245312462.

Gohli, J., Kirkendall, L., Smith, S., Cognato, A., Hulcr, J., Jordal, B. (2017). Biological factors contributing to bark and ambrosia beetle species diversification. International Journal of Organic Evolution 71(5): 1258-1272.

Hammer, Harper, D., Ryan, P. (2001). PAST: Paleontological Statistics Software Package for Education and Education and Data Analysis. Paleontologia Electronica 4(1).

Hulcr, J., Atkinson, TH., Cognato, AI., Jordal, BH., \& McKenna, DD. (2015). Morphology, Taxonomy, and Phylogenetics of Bark Beetles. Bark Beetles: Biology and Ecology of Native and Invasive Species. https://doi. org/10.1016/B978-0-12-417156-5.00002-2

Hulcr, J., Beaver, RA., Puranasakul, W., Dole, SA., \& Sonthichai, S. (2008). A comparison of bark and ambrosia beetle communities in two forest types in northern Thailand (Coleoptera: Curculionidae: Scolytinae and Platypodinae). Environmental Entomology, 37, 14611470. https://doi.org/10.1603/0046-225X-37.6.1461

IPCC. (2013). Climate change 2013: the Physical Science Basis. In: Stocker TF, Qin D, Plattner GK, Tignor MMB, Allen SK, Boschung J, Nauels A, Xia Y, Bex V, Midgley PM (eds) Contribution of Working Group I to the Fifth Assessment Report of the Intergovernmental Panel on Climate Change. Cambridge University Press, Cambridge, p 986

IUFRO. (2017). International Union of Forestry Research Organizations. Disponible en www.iufro.org. [Accedido el 08 de agosto de 2017].

Iturre, M., \& Darchuck, E. (1996). Registro de escolítidos relacionados al género Eucalyptus en Santiago del Estero. Quebracho, 4, 11-16.

Jaramillo, JL., Ospina, CM., Gil, ZN., Montoya, EC., \& Benavides, P. (2011). Avances en la biología de Corthylus zulmae (Coleoptera: Curculionidae) en plantaciones de Alnus acuminata (Betulaceae). Revista Colombiana de Entomologia, 37(1), 48-55.

Kangkamanee, T., Sittichaya, W., Ngampongsai, A., Permkam, S. \& Beaver, R. (2011). Wood-boring beetles (Coleoptera: Bostrichidae, Curculionidae: Platypodinae and Scolytinae) infesting rubberwood sawn timber in
Southern Thailand. Journal of Forest Researche, 16, 302 -308 .

Kirkendall, LR., Biedermann, PHW., \& Jordal, BH. (2015). Evolution and Diversity of Bark and Ambrosia Beetles. Bark Beetles: Biology and Ecology of Native and Invasive Species. https://doi.org/10.1016/B978-0-12417156-5.00003-4

Kjohl, M., Nielsen, A., Stenseth, NC., Alván, LES., Jiménez, M., Olivero, S. (2012). Informe especial sobre la gestión de los riesgos de fenómenos meteorológicos extremos y desastres para mejorar la adaptación al cambio. Resumen para responsables de políticas. Grupo Intergubernamental de Expertos sobre el Cambio Climático, San José (Costa Rica). Recuperado a partir de http://www.sidalc.net/ cgibin/wxis.exe/?IsisScript=orton.xis\&\&B1=Buscar\& formato $=1 \&$ cantidad $=50 \&$ expresion $=$ FACTORES $\% 20$ CLIMATICOS

MAGAP, (2015). Ficha informativa de proyecto de Establecimiento de 120000 hectareas de plantaciones forestales con fines comerciales a nivel nacional. Recuperado: http:servicios.agricultuta.gob.ec

Midgley, S. Blyth, M., Howcroft, N., Midgley, D., \& Brown, A. (2010). Balsa: biology, production and economics in Papua New Guinea. (Rep. Tec. No. 73) Australian Centre for International Agricultural Research. Camberra, Australia. 98p.

Morales, N., Zanuncio, J., Pratissoli, D., Fabres, A. (2000). Fluctuación poblacional de Scolytidae (Coleoptera) en zonas reforestadas con Eucalyptus grandis (Myrtaceae) en Minas Gerais, Brasil. Revista Biología Tropical, 48 (1): 101-107.

Nair, KSS. (2001). Insect pest and Disease in Indonesian Forestas. Bogor: Center for International Forestry Research. 91 p.

Nicholls, CI., Henao, A., \& Altieri, MA. (2017). Agroecología y el diseño de sistemas agrícolas resilientes al cambio climático. Agroecología, 10(1), 7-31.

Pereira da Silva, JC., Pinheiro, G., Flechtmann, C. (2015). Influence of tapping on the Abundance of Scolytinae and Platypodinae (Curculionidae) in Hevea brasilisis in Northwestern Sao Paulo State (Brazil), 4 pp. In Proceedings: 4th Congresso Brasileiro de Heveicultura, 24 - 26 June 2015, Sao José do Rio Preto.

Pérez de la Cruz. (2008). Diversidad y abundancia de escolítidos (Coleoptera: Scolytidae) asociados al agroecosistema de cacao en Tabasco, México. Tesis de Doctor en Ciencias, Colegio de postgraduados. Montecillo, Texcoco, México.

Rangel, R., Pérez, M., Sánchez, S., Capello, S. (2012). Fluctuación poblacional de Xyleborus ferrugineus y $X$. affinis (Coleoptera: Curculionidae) en ecosistemas de Tabasco, México. Revista de Biologia Tropical, 60(4), $1577-1588$.

Rudinsky, J. (1962). Ecology of Scolytidae. Annual Review of 
Entomology, 7: 327-348

Sittichaya, W., \& Beaver, R. (2009). Rubberwood-destroying beetles in the eastern and gulf áreas of Thailand (Coleoptera: Bostrichidae, Curculionidae: Scolytinae and Platypodinae). Songklanakarin Journal of Science and Technology, 31, 381-387.

Smith, SM., and Cognato, A. (2016). A Revision of Coptonotus chapuis, 1869 (Coleoptera: Curculionidae: Coptonotinae) with notes on its biology. The Coleopterists Bulletin. 70(3): 409-428.

Stilwell, AR., Smith, SM., Cognato, AI., Martinez, M., FLowers, W. (2014). Coptoborus ochromactonus, n. sp. (Coleoptera: Curculionidae: Scolytinae ), an emerging pest of cultivated balsa (Malvales: Malvaceae) in Ecuador. Journal of Economic Entomology, 107(2): 675-683.
Vásquez, ML., Rodríguez, M., Zorrilla, ML. (2003). Lista de escolítidos (Coleoptera) de Cuba y sus plantas hospedantes. Revista Fitosanidad. 7(1).

Wood, SL. (2007). Bark and beetle ambrosia of the South America (Coleoptera, Scolytidae). Brigham Young University. Provo, Utah USA. 909p.

Wood, SL., \& Bright, DE. (1992). A catalog of Scolytidae and Platypodidae (Coleoptera), Part 2: Taxonomic Index Volume B. Great Basin Naturalist Memoirs. 1310p.

Zanuncio, JC., Sossa, MF., Flechtmann, CA., Zanuncio, TV., Guimaraes, EM., Espindula, MC. (2005). Plants of an Eucalyptus clone damaged by Scolytidae and Platypodidae (Coleoptera) sa Agropecuaria Brasileira, 40(5): 513-515. 